\title{
RAGASZTÓFELHORDÓ BERENDEZÉS TERVEZÉSE
}

\section{DESIGN OF A GLUE APPLYING MACHINE}

Bekő Balázs ${ }^{1}$, Szigeti Ferenc ${ }^{2}$

Nyíregyházi Egyetem, Múszaki és Agrártudományi Intézet, Müszaki Alapozó, Fizika és Gépgyártástechnológia Tanszék. Nyíregyháza, Magyarország

${ }^{1}$ bekobalazs2@gmail.com

${ }^{2}$ szigeti.ferenc@nye.hu

\begin{abstract}
The glue applying machines allow the glue application to tableware during production. The purpose of my dissertation is to solve certain problems with a development of a new machine. In my dissertation I'm going to expound my measurements and tests what I made before the new machine's design, the parts of the machine what I've planned and a load simulation of a part, which has a critic cross-section.
\end{abstract}

Keywords: glue application, glue application measurement, finite element test, design of a machine.

\section{Összefoglalás}

A ragasztófelhordó gépek lehetővé teszik a nagyipari gyártás során a terítékre történő ragasztófelhordást. A dolgozat célja a ragasztófelhordás során jelentkező problémák megoldása egy új konstrukció kifejlesztésével. A dolgozatban bemutatom a tervezést megelőzően elvégzett méréseket, vizsgálatokat, valamint az új konstrukció fontosabb részeit, továbbá a berendezés tartóvázánál egy veszélyes keresztmetszetnél végeselem módszerrel készített szimulációt.

Kulcsszavak: ragasztófelhordás, ragasztófelvitel mérés, végeselem vizsgálat, géptervezés.

\section{Bevezetés}

A dolgozatom témáját a duális képzésben résztvevő egyik partnervállalat, a nekem is gyakorlati helyet nyújtó Eissmann Group Automotive Hungaria Kft. [1] biztosította számomra.

Azért választottam ezt a témát, mert felkeltették érdeklődésemet a vállalatnál alkalmazott ragasztófelhordási technikák és javaslataim kidolgozásával szeretnék hozzájárulni a ragasztófelhordás minőségének és gazdaságosságának javításához.

Dolgozatomban először bemutatom a ragasztófelhordó gépek jellemzőit, alkalmazásuk előnyeit, hátrányait. Kiemelten foglalkozom a Fortuna ECOL 200-as típussal, amely vizsgálataim tárgyát képezte. Bemutatom a gép működtetése során fellépő jellemző problémákat, majd ismertetem a ragasztófelvitelre vonatkozó vizsgálatokat, a konstrukciós változtatásokat, valamint az új megoldásokat a feltárt problémák kiküszöbölésére.
A munkám célja a problémák megoldása egy új konstrukció tervezésével, amely lehetővé teszi az egyenletes ragasztófelhordást, a felhasznált ragasztó mennyiségének csökkentését, ugyanakkor szerelése, beállítása, karbantartása egyszerübb.

\section{A Fortuna típusú gép használatánál felmerülő problémák}

A Fortuna ECOL 200 típusú gép [2] hibái: foltos ragasztófelvitel, valamint a műszak végén a tálcában maradó és kidobásra kerülő 2,8 dl mennyiségű ragasztó. Ez egy berendezést tekintve éves szinten 250.000,- Ft veszteség. Fontos szempont az is, hogy műszak végén a dolgozó minél könnyebben tudja kivenni a felhordóhengert tisztításra, jelenleg nemcsak a hengert és annak a tengelyét veszi ki, hanem a tengelyre erősített fogaskereket is, így nagyobb tömeget kell emelnie a dolgozónak. Problémát jelent a két henger tengelye kö- 
zötti távolság állítása is, ami pillanatnyilag körülményes, sok időt vesz igénybe.

\section{A ragasztófelhordással kapcsolatos mérések}

Méréssel határoztam meg a ragasztófújás és a gépi felhordás közötti különbséget, kísérlettel igazoltam, mennyi veszteséggel jár, ha fújópisztolylyal viszik fel a ragasztót a bőrfelületre a gépi ragasztófelhordáshoz képest. Az 1. táblázatból kiderül, hogy a fújással felvitt ragasztó közel 60\%-a veszendőbe megy. Ez egy fújókabint tekintve éves szinten nagyjából 700.000,- Ft veszteség, és több kabin is található a termelés területén.

A vizsgálatok alapján tehát előnyösebb a kabinok helyett ragasztófelhordó gépet használni, legalábbis azon fújókabinok helyett, ahol nem olyan bőrre viszik fel a ragasztót ami már varrva volt. A varrott bőrfelületet ugyanis nem lehet ragasztófelhordó gépen átengedni (általában a bőrt formára varrják, pl. a sebességváltó szoknyáját). Továbbá fújást kell alkalmazni a műanyag fröcscsöntött alkatrészek ragasztófelhordásánál is.

Továbbá mikroszkópos felvételeket is készítettem a vállalat laboratóriumában található DNT DigiMicro Profi típ. mikroszkóppal, 32x-es nagyításban. A vizsgálat célja annak megállapítása volt, hogy melyik henger felületi mintázata, kialakítása eredményez egyenletesebb ragasztóeloszlást a bőr felületén. A vizsgálatokból kiderült, hogy minél kisebb egy henger felületi érdessége, annál egyenletesebb a ragasztófelhordás. A megfelelő felületi érdességre pedig azért van szükség, mert ez a feltétele a ragasztó hengeren maradásának.

Az 1. ábrán a Fortuna ECOL 200-as berendezés gyári, recézett felületű acélhengerének a mikroszkópos képe, a 2 . ábrán pedig a henger által a bőrre felvitt ragasztó látható.

Megállapítható a 2. ábra alapján, hogy a felvitt ragasztóréteg nem egyenletes eloszlású. Egy másik berendezés homokszórt felületű ragasztófelhordó hengere viszont a mikroszkóp alatt ennél sokkal egyenletesebb eloszlást biztosít a bőr felületén, viszont annak az előállítása költségesebb a Fortuna gyári hengerénél.

1. táblázat. A fújás veszteségei

\begin{tabular}{|c|c|c|c|}
\hline \multicolumn{4}{|c|}{ 35 darab termék fújása } \\
\hline $\begin{array}{c}\text { Ragasztó } \\
\text { súlya a } \\
\text { börőn } \\
\text { (g) }\end{array}$ & $\begin{array}{c}\text { Pisztolyból } \\
\text { hiányzó } \\
\text { ragasztó } \\
\text { (g) }\end{array}$ & $\begin{array}{c}\text { Veszteség } \\
\text { (g) }\end{array}$ & $\begin{array}{c}\text { Veszteség } \\
\text { (\%) }\end{array}$ \\
\hline 29,64 & 69,61 & 39,97 & 57,42 \\
\hline
\end{tabular}

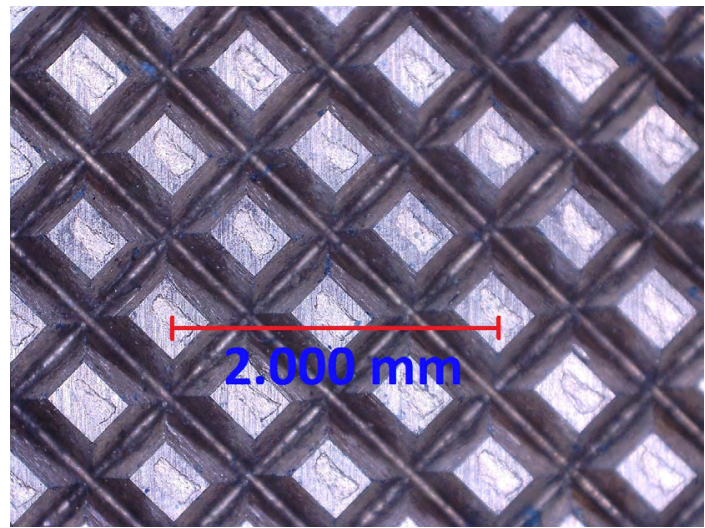

1. ábra. Recézett felületü henger

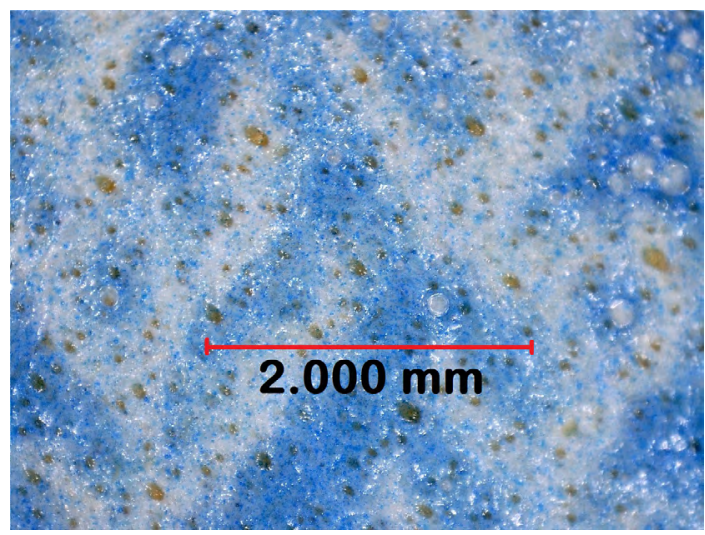

2. ábra. A recézett felületü henger által felvitt ragasztó képe a börön

\section{A Fortuna berendezést kiváltó új gép terve}

A továbbiakban bemutatom az általam tervezett új berendezést, valamint annak részegységeit, azok funkcióit. Az egyik alkatrészen található egy veszélyes keresztmetszet, bemutatom az erre készült statikus terheléses végeselem szimulációt, amely alapján megválaszthattam az alkatrész anyagminőségét. Az áttervezett ragasztófelhordó berendezés a 3. ábrán látható.

A $220 \mathrm{~W}$-os villanymotor valamint a $114 \mathrm{~mm}$ átmérőjű és $200 \mathrm{~mm}$ hosszú recézett felületű acélhenger átkerülnek a Fortunából ebbe a gépbe, viszont ez a henger az új konstrukció esetében már nem ragasztó felvevő és felhordó, hanem csak felvevő. Átadja a ragasztót egy gumihengernek és az lesz a felhordó, így egyenletesebb ragasztófelhordás biztosítható, mint amilyet a Fortuna recézett felületű acélhengere tesz lehetővé. Ezzel a felhordás folyamata a flexo nyomtatásra [3] fog hasonlítani, mert ott is egy kemény felületű henger adja át egy rugalmasnak a ragasztóanyagot. 
A ragasztólehúzást az új konstrukciónál a Fortuna ECOL 200-as berendezés ragasztólehúzójának pontosságától jóval finomabban lehet majd beállítani (3.3. pont).

$\mathrm{Az}$ áttervezett berendezés alkatrészeit a SolidWorks háromdimenziós tervezőprogramban készítettem el számos mérés, méretezés és vázlatkészítést követően. A részletrajzokat végül egy összeállítási fáljban egymáshoz illesztettem (3. ábra). A modell tartalmaz minden alkatrészt, valamint a kötő- és hajtáselemeket is (a fogasszíjat leszámítva).

\subsection{A ragasztós tálca}

A tálcát úgy terveztem meg, hogy ha ki van öntve minden irányban $3 \mathrm{~mm}$ vastagon szilikonnal, akkor a ragasztófelvevő henger minden irányból 2 mm távolságban van tőle (4. ábra). Így minimálisra csökken a műszak végén a tálcában maradó ragasztómennyiség. A szilikonos öntést segítendő, terveztem egy ellentálcát is, amit rá kell a tálcára helyezni és a szilikon kötéséig rajta is kell hagyni. Így az ellentálca $3 \mathrm{~mm}$-re van minden irányban a tálca belsejétől.

\subsection{Tengelytávolság állítás}

A tengelytávolság állítási lehetőségét úgy terveztem meg, hogy a két felső henger közötti távolság a felső, ellenhenger csapágyházaiban lévő furatokban helyet foglaló menetes orsók forgatásával legyen állítható. A ragasztófelvevő és a felhordó henger (melyek között dörzshajtás van) közötti táv pedig úgy állítható, hogy közben nem módosul a két felső henger közötti távolság. Ezt úgy terveztem meg, hogy a felső tartókban van együtt a felhordó valamint az ellenhenger csapágyháza, és az egész felső tartót lehet egy csavarorsó állításával mozgatni, valamint az optimális állásban az orsót anyával lehet rögzíteni (5. ábra).

\subsection{A ragasztólehúzó}

Egy lehúzó lemezzel lehet szabályozni a hengerre felkerülő ragasztó mennyiségét (6. ábra). Az általam tervezett ragasztólehúzó sokkal pontosabb beállítási lehetőséget biztosít az ECOL 200-as lehúzójához képest. Ezt nem vízszintesen lehet állítani hanem függőlegesen. Mivel a tengely középvonalától 20 mm-rel van magasabban a lehúzó lemez, függőlegesen $1 \mathrm{~mm}$ elmozdulás vízszintesen pár tized mm-t jelent csak (7. ábra). Így az eddiginél lényegesen nagyobb pontossággal lehet beállítani a felvitelre szánt ragasztófilm vastagságát.

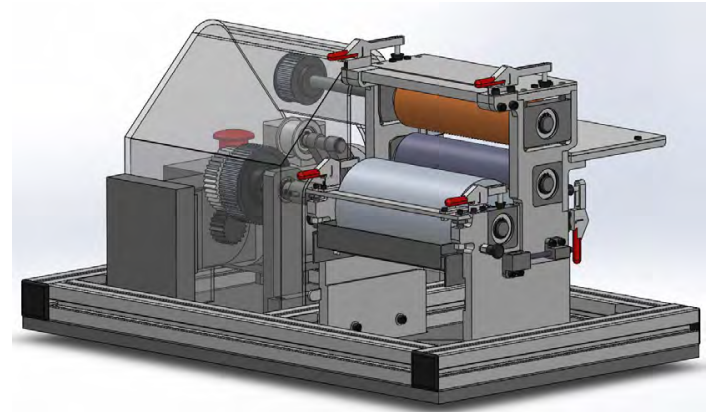

3. ábra. A konstrukció SolidWorks-ben

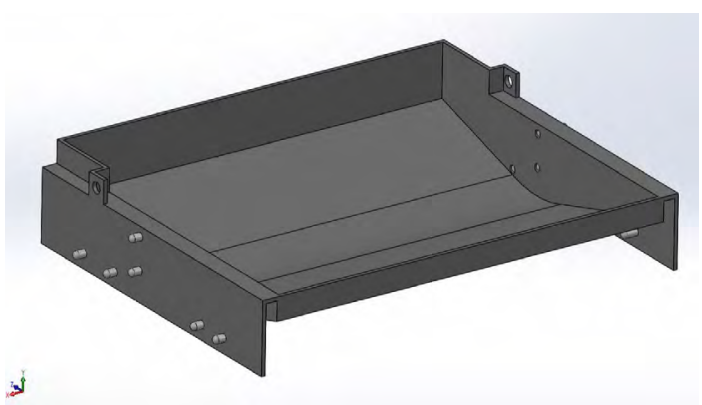

4. ábra. A ragasztós tálca

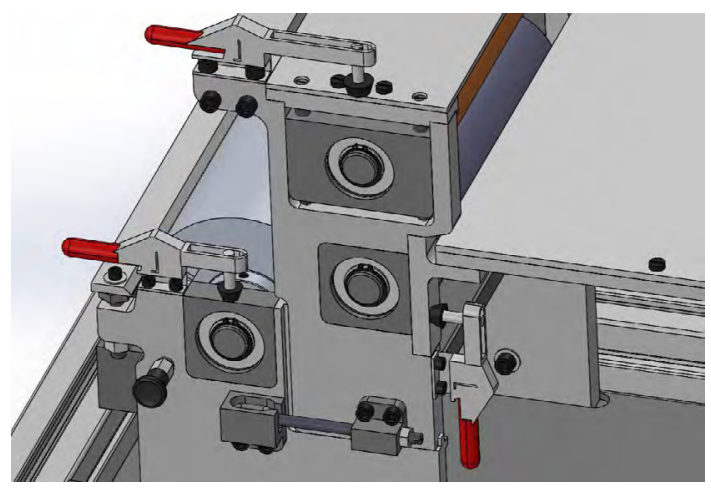

5. ábra. A tengelytávolság állítása

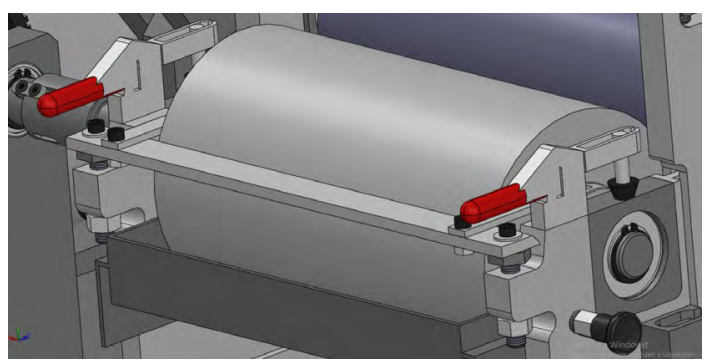

6. ábra. A agasztólehúzó lemez 


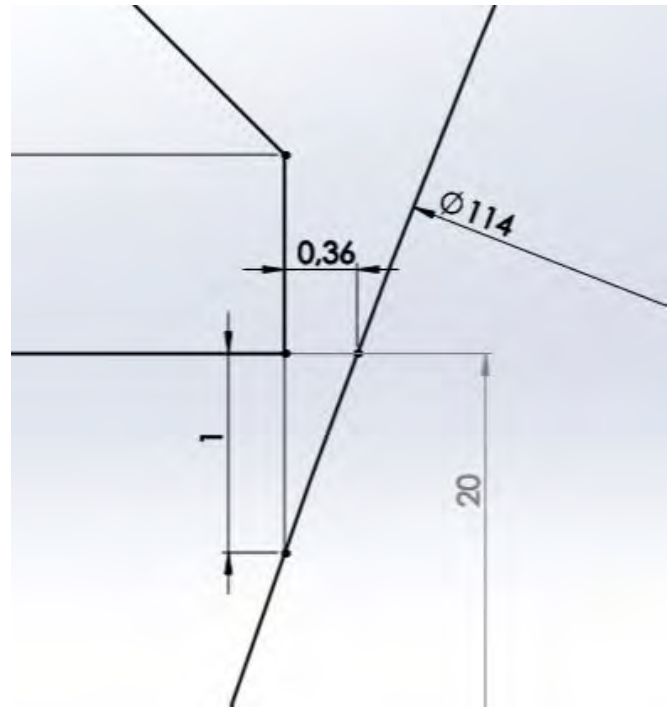

7. ábra. A ragasztólehúzó lemez - vázlat

\subsection{A tengelykapcsoló}

Jelenleg a Fortunánál műszak végén, amikor meg kell tisztítani a felhordóhengert, a dolgozó az egész tengelyt veszi ki, amelyen a fogaskerék is rajta van. Az új konstrukció lehetővé teszi a tengely kiszerelését a többi hajtáselem elmozdítása nélkül egy tengelykapcsoló segítségével, amelyben egy rugó van elhelyezve.

A rugón egy tengelykapcsoló tok helyezkedik el, amit ha kézzel elhúz a dolgozó, a másik kezével pedig az alsó jobbos tartóra szerelt, könnyen levehető 15-ös villáskulccsal elfordítja az acélhenger tengelyét a lapolásnál, az már nem fog összezárni és ki tudja emelni a hengert a csapágyházainál fogva, a többi hajtáselem elmozdítása nélkül (8. ábra).

\subsection{Végeselem szimuláció}

A berendezés tartóvázán található egy veszélyes keresztmetszet (9. ábra). Bemutatom a statikus terhelésre készített végeselem szimulációt, amely lehetővé tette az alkatrész anyagminőségének helyes megválasztását.

\subsection{A hengerek}

A Fortuna berendezés működtetésénél az egyik probléma a foltos ragasztófelvitel volt. Megfelelő henger választásával ez a probléma megoldható. A gupfo.com internetes áruházban találtam a géphez alkalmas hengereket. Felhordónak gumit célszerű alkalmazni mert az nem szívja be magába a ragasztót, viszont rugalmas, ellenhengernek pedig használható a valamivel olcsóbb szivacs is, mivel az nem érintkezik ragasztóval.

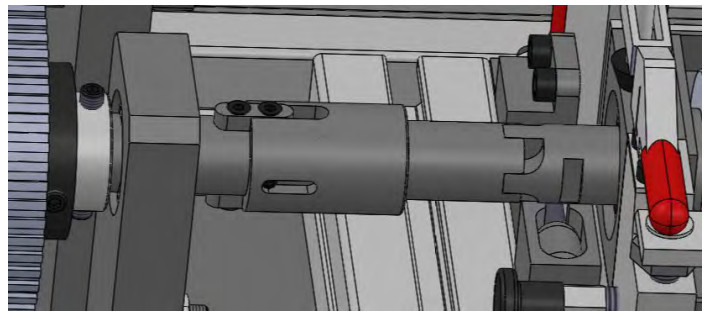

8. ábra. A tengelykapcsoló

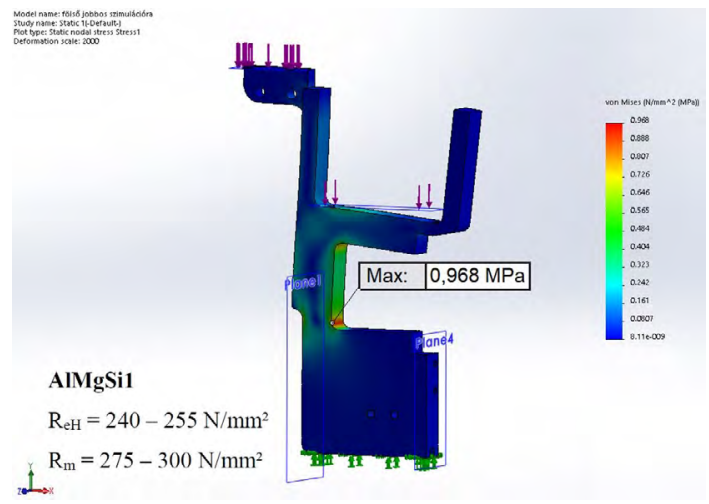

9. ábra. Terheléses szimuláció

A rugalmas hengerekhez pedig kemény fém vagy müanyag tálcát alkalmazok, amire a bőrt ragasztják ideiglenesen, így elméletileg nem lesz foltos a ragasztófelvitel (mivel hiába nyomja rá a dolgozó a bőrt a tálcára, az nem veszti el az alakját).

\section{5. Összefoglalás}

Feltártam a Fortuna ECOL 200 típusú ragasztófelhordó berendezés problémáit; méréseket és vizsgálatokat végeztem, a levont következtetések segítségével pedig megterveztem az üzemi igényeknek megfelelő gépet.

Elkészítettem az új konstrukció szerelési dokumentációját is [4]. Az elkészített tervdokumentáció alapján az új ragasztófelhordó berendezés legyártható.

\section{Szakirodalmi hivatkozások}

[1] Eissmann Automotive, History

https://www.eissmann.com/en/the-company/history.html

[2] A Fortuna ECOL 200 gépkönyve

[3] Magyar nyomdász, A flexó nyomtatás https://www.magyarnyomdasz.hu/a-flexo-nyomtatas

[4] Jánossy Gy., Zsidai L., Kári-Horváth A.: Szereléstechnológiák. Nemzeti Munkaügyi Hivatal, 2014. 